\title{
Dialogue between Islam and West
}

\author{
Nazar ul Islam Wani
}

\begin{abstract}
Islam and the West are the two civilisations which have gained importance in the present world Order. The Islam, because of its strategical locations in the middle-east and presence of conflict zones like Palestine and Kashmir. The west, because of its relations with the Muslim countries makes both these civilisations a headline for the global media. The study of the relation between these two civilisations has shaped the curriculum of International Relations (IR) for the IR students worldwide. The relation between the two civilisations has also been debated a lot in hundreds of chat rooms, in TV shows, in newspaper columns, in thousands of websites in Cyberspace, in school debates and workplaces over small issues like face covering and the Danish cartoons of 2006.

John Esposito says that the "two communities, Islam and West, has always been in competition and locked at times in deadly combat, for power, land and souls". . Across the centuries the fortunes of the two religions have risen and fallen in sequences of momentous surges, pauses and counter surges ${ }^{2}$. This work strives to explore west in relation with Islam, with an effort to create the room for dialogue between these two communities. This work also strives to look into these civilisations through the prism of religion.
\end{abstract}

\section{Western civilisation:-}

This Civlisation emerged as agreed by some scholars in 700 AD. It's generally viewed by scholars as having three major components in Europe, North America and Latin America. It is the only civilisation identified by a compass direction and not by the name of a particular people, religion, or geographical area $^{3}$.There is a consensus among the scholars that modern Western civilisation is the outcome of Greek and Roman civilisation, and Christianity has great intimacy with this civilisation since its birth.

Christianity took its root from within the frame work of Judaism, absorbed and adopted a large number of elements and practices from Judaism. The message the Jesus Christ (Peace be upon Him) preached was not different from the Muhammad's (peace be upon him) message. Jesus Christ (Peace be upon him) tried to unite the people under the banner of one God, Tawhid, and taught the concept of Universal brotherhood and equality.

The establishment of Christianity as the official religion of the Roman Empire, made possible due to the conversion of Constantine into the Christianity in AD 305, was a turning point in the religious establishment of Western Civilisation. The church became paramount. It achieved power and wealth. The Christians proved themselves strong to give a master to the Empire but it was never strong to destroy its antagonist, paganism. The issue of struggle between the paganism and Christianity differed Christianity from Islam which absolutely and seriously annihilated its antagonist and spread its doctrines by without extraneous addition. The moral conditions of the Romans suffered devastation due to the amalgamation of Christianity and paganism. People were fed up of the Roman inclinations towards religion as antagonistic. They on the other hand produced a great flare-up of monasticism, asceticism, the aim of which was the sordid and atrocious self-torture. The cleanliness of the body was regarded as the pollution of the soul. Some monks would not wash their hands for a long time. And lead to the societal damage including family foundations. Monasticism never helped, it gave a huge set back to Christianity. It was considered sinful to converse even with your own mother, wife and sister. And monasticism yielded the corrupt clergy in such a way that the whole revenues of France were insufficient to meet the expenditure of the Popes ${ }^{4}$.

During the Middle Ages church enjoyed the power more than the Roman Emperors. The church dominated the whole aspects of life, be it intellectual or social or political or spiritual. It is in this period that many scientists, intellectuals were deprived of their intellectual activity. No theory was accepted which was against the doctrine of the church. Philosophy or reason dominated the revelations which lead the Christianity to stand before the argument of those like, Islam or Muslims who did not accept the validity of the Christian revelation ${ }^{5}$.

The domination of faith by the reason resulted in the pollution of scriptures. Consequently, a conflict was witnessed between Science and Christianity. Galileo, for example, was beaten severely till he died in the prison for having held, contrary to the scriptures that the earth moved round the sun! The brawl between the secular and religious knowledge persisted in Europe for a long time.

At last, the revolt started against the traditions of the representatives of Christianity. In thirteenth century AD due to the growth of rich commercial class in Italy and then in other parts of Europe, who were as 'intelligent as the clergy', the church began to lose its hold. In the process papacy lost the moral prestige which it had enjoyed. The result was the Enlightenment in Europe which gave birth to too many ideologies like 
individualism, liberty etc, in which the reason was considered to be the sole authority of the knowledge. This is witnessed with the growth of science and scientific thinking ${ }^{6}$.

This never ended here says Abul Hassan Nadwi makes a good point, that the freedom which they enjoyed started to argufy between the religion and secular knowledge, outburst into an all out contest between the religion and progress. It was concluded arbitrarily by the intelligentsia of Europe that the religion was incompatible with science. Consequently, for the encouragement of Science the discouragement of religion was necessary.

It's from here that the western civilisation starts looking different from the Islamic civilisation. Let see the assorted views of the scholars regarding the western civilisation

Abul Hassan Ali Nadwi says in Islam and the Modern World that the Greek civilisation was totally materialistic. The Greeks could not conceive the God without giving Him the material shapes. They had a god of sustenance, a god of benevolence, a god of fury, and so on. All the attributes of the physical existence were ascribed to these gods. The aim was to develop the man harmoniously. The religion of Greeks had no spirituality, no theology and no mysticism.

While discussing the Roman civilisation Nadwi says that the religion in Rome was in truth nothing more than a social tradition and utilitarian formulae. He quotes Lecky, an Irish historian, in the History of European Morals, who says that the 'Roman religion was purely selfish'. For him the religion of Rome was a method of obtaining the prosperity, averting calamity and reading the future. He quotes again William Lecky according to whom; the ancient room produced many heroes, but no saints ${ }^{7}$.

Dr. Yussuf Al Qardawi, Egyptian Islamic Theologian, says Contemporary Western civilisation is based on deep-rooted intellectual foundations that date back as far as ancient Greek and Roman cultures. Five characteristics of Western thought were brilliantly outlined by Dr. Yussuf Al Qardawi as follows:

1- The flawed knowledge of the divinity: Western perception underlying Western civilisation does not have a neat, clear-cut vision of God living up to His true dimensions. It is rather a hazy and blurred vision.

2- The materialistic propensity which believes in the primacy of matter as a basis for understanding the universe, knowledge and behaviors, denying at the same time the metaphysical and spiritual dimension.

3- The secular tendency, which is the upshot and the corollary of the two preceding characteristics. It is a tendency which separates religion from social life.

4- Conflict: It is a civilisation pervaded by conflict, a civilisation which does not believe in peace, quietude or love. It is marked by conflict between man and himself, between man and his fellows and finally between man and his Creator.

5- Feeling of superiority: It is a drive which is deeply ingrained in the mind of all Westerners. They consider themselves to be superior to others and believe that Western civilisation is synonymous to Human Civilisation. They recognize no other civilisation.

The positive aspects of Western civilisation:

To be fair in our analysis, we should admit that Western civilisation has positive aspects benefitting humanity. It offers a lot of advantages and, above all, shares many positive sides with the Islamic civilisation.

Western civilisation was able, thanks to the progress of mathematics, natural science and their technological applications, to provide man with unprecedented and undreamt of capabilities and opportunities. It offered means, tools and apparatuses that were never available before, and reduced distances, bringing remote locations closer while saving time, thanks to modern means of transportation which are permanently improved, to the extent that the world has become a planetary village.

The first industrial era spared man the physical effort, thanks to the introduction of machines. In the second industrial era, the computer which carries out tremendously complex operations spared man the mental effort. Computer technology has been introduced into the Islamic scientific life, especially in the disciplines related to the study of the Quran, the Prophetic Tradition, linguistics, literature and many other disciplines ${ }^{8}$

Said Nursi, a Muslim modernist from Turkey, says what we are accustomed to call "modern civilization" or "Western civilization" Said Nursi usually referred to as "European civilization," or simply as "Europe." This is logical, since modernity, not only in the sense of scientific and technological advances, but also in its philosophical underpinnings, first took root in Europe and from there was brought to every corner of the world. Like Yusuf al Qardawi he also discusses the two aspects of western civilisation. He makes a remarkable statement that the 'Europe is two' or 'western civilisation is two' like:

"'One follows the sciences which serve justice and right and the industries beneficial for the life of society through the inspiration it has received from true Christianity; this first Europe I am not addressing. I am rather addressing the second, corrupt Europe which, through the darkness of the philosophy of naturalism, supposing the evils of civilisation to be its virtues, has driven mankind to vice and misguidance ${ }^{9} . "$

Are we at stage where we can say that the western civilisation from its very inception lacked the religious spirit? Muhammad Asad says in Islam at the Crossroads that the religion that rules over the mind and spirit of West today is not the Christianity but the Materialism. He says that there are people in the west who feel and think in a religious way but these are exceptions. He further says: 
"The average occidental- be he a Democrat or a Fascist, a capitalist or a Bolshevik, a manual worker or an intellectual- knows only one positive religion and that is the worship of material progress....The temples of this religion are the gigantic factories, cinemas, chemical laboratories, dancing halls, hydro-electric works; and its priests are bankers, engineers, film stars,..."

One can understand that the western civilisation is full of material progress but since its inception it definitely lacked the religious fervor. The foundation of the western civilisation on which it has made its cultural structure is materialism and it has alienated the religion virtually from the hearts of its people. It's true that modern western Civlisation has served the mankind technologically and through many other sources of knowledge but it has also created a disastrous God- forgetfulness in the minds and hearts of the people. The brunt of which mankind cannot bear for centuries.

\section{Islamic civilisation:-}

This civilisation originated in the Arabian Peninsula in the seventh century AD., Islam spread rapidly across the North Africa and the Iberian Peninsula and also eastward in Central Asia, the Subcontinent and Southeast Asia. Consequently many cultures exist within this civilisation, including Arab, Turkish, Persian and Malay $^{11}$.

Maulana Maududi explores the concept of Islamic civilisation. He says:

"What is basically an Islamic civilisation? What do people understand by the name Islamic civilisation? Is Islamic Civlisation, the collective name given to some nation states which are created in the name of nationalism, like Egypt and Turkey? People consider nations as civilisations because of their development in language, Art, Architecture, literature, economy, politics etc. But these are actually not the soul of civilisations; they can be characteristics, features, external appearances, pomp and show etc., of civilisations but not the essence of civilisations. Besides that one must reach and search the inner core of civilisations". Further in his book, he says that the inner core of Islamic civilisation is Islam. ${ }^{12}$

This civilisation started to lay in its roots at the dawn of seventh century of Christian era. In the streets of Mecca, a city of considerable importance among the township of Arabia, Prophet Muhammad (peace be upon him), the last prophet of God, started preaching among the pagans of Arabia, the revelation received from God through the arch angel Gabriel. It was not an easy task to preach in a land, bleeding and torn with fratricidal wars and inter-tribal dissensions. The land, which Alexander- the Great found useless to conquer because of its lawlessness. Prophet Muhammad (peace be upon him) would soon revolutionize the hearts of pagans and turned them into worship. Like all other Prophets, Muhammad also suffered persecution, even with more intensity by the bureaucracy of Mecca, the Koreish. The persecution and the wave of intense struggle crossed the frontiers of patience, which was now unbearable for the companions of the Holy prophet. Consequently under the consistent guidance of God, the great migration in $621 \mathrm{AD}$., took place to Medina. The migration turned everything into gold. It is the same date from which Muslim calendar starts; Hijri. The life in Medina was totally different from the life in Mecca. In Medina by the support of Ansar, the real inhabitants of the land of Medina, the Prophet became the Hero with a large mass footage around him. He stabilized the whole of Medina and made it an Islamic state based on the teachings of Quran and prophet's own wisdom.

Medina promised a substantial base for the progress of Islam. It is from here that many battles were fought with the Koreish and many Jewish tribes. The first job was to prove Islam at global level, which they did with fair preaching and wisdom. Latter on when wisdom failed to deliver before Koreish, they crushed the power of Koreish in the historically important battle, the battle of Badr. The Islam and its followers became increasingly successful in conquering their original homeland, Makkah, in 630 AD. The date is remembered as Human Rights Protection Day in the history of Islam, because the attitude of forgiveness was shown towards the staunch enemies of Islam. Afterwards, Islam established its roots firmly with the help of military might in the shape of companions, who still in the eyes of billions of Muslims are the best generation ever lived on earth, because of their in-depth love for the God and Prophet.

The unique love and reverence was shown to the Prophet by His companions. This love was expressed by the 'Urwa before his Koreish brethren on his return from Hudabiyah, a ten year pact signed between Muslims and the Koreish. He expressed the unprecedented obedience to the Prophet by His followers. He said that he has witnessed the Caesar, Khusraw and Negus but never had seen any king held in greater respect by His subjects than Muhammad by His companions. Prophet (peace be upon him) was able to bring the most stupendous change in the human history. A new Ummat came into being, the members of which were surprisingly the all humankind. Never had before come such harmonious body of men, on the stage of history ${ }^{13}$.

Prophet Muhammad (peace be upon him) passed away in 632 AD., but before announcing a message which was unlike of previous prophets and nations, that is, to preach this message loudly, there is no God but Allah and Muhammad is the last Messenger of Allah, to those living in any corner of the world. He was followed by four rightly guided Khalifas, Abu Bakr, Umar, Uthman and Ali (May Allah be pleased with them). They all ruled with Justice, unprecedent in the annals of history. Their rule lasted for thirty years and during that time Islam reached far across the distance inside the Persian and Byzantine Empire and into the heart of 
subcontinent. Islam not only spread through the conquests but millions of people embraced the teachings of Quran and Hadith (sayings and doings of prophet). The belief in One God and the last Prophet was accepted and admitted to be the real purpose of life which became the cognitive content of the Islamic Civilisation.

In the early 7th century AD, Prophet Muhammad (peace be upon him) and successive caliphs took up the Arabic custom of making raids against their enemies. The Qur'an called these raids the jihad ("striving in the way of the Lord"). The jihad was not carried out as a means to convert others for the simple reason that acts of conversion to the Islamic faith were voluntary. The Byzantines and Persians were the first to feel the pressure of Arab raids. At Yarmuk in 636, the Muslims defeated the Byzantine army. Syria fell in 640. A decade later, the Muslims had conquered the entire Persian Empire. Egypt, North Africa and Spain (with its center at Córdoba) were all conquered and under Muslim rule by the 720s. In 732, a Muslim army was defeated at the Battle of Tours, and Muslim expansion in Europe came to an abrupt halt.

In the 8th and 9th centuries, under the Abbasid caliphs, Islamic civilization entered a golden age. Arabic, Byzantine, Persian and Indian cultural traditions were integrated. And while in Europe, learning seemed to be at its lowest point, the Muslims created what I suppose could be called a "high civilization." Thanks to Muslim scholars, ancient Greek learning, acquired from their contact with Byzantine scholars, was kept alive and was eventually transferred to the West in the 12th century and after. But not only did Muslim scholars preserve the heritage of Greek science and philosophy, they added to it by writing commentaries and glosses, thus adding to what eventually became the western intellectual tradition. Throughout the Qur'an one can find a strong emphasis on the value of knowledge in the Islamic faith. The Qur'an encourages Muslims to learn and acquire knowledge, stemming from, but not limited to, the Muslim emphasis on knowing the unity of God. Because Muslims believe that Allah is all-knowing, they also believe that the human world's quest for knowledge leads to further knowing of Allah ${ }^{14}$.

\section{Relation between Islamic and Western Civlisation:-}

Samuel P Huntington says the following on the relation between Islam and Christianity

"The relations between Islam and Christianity, both orthodox and western, have often been stormy. Each has been other's other... ${ }^{15}$,

Allah says in the Glorious Quran "say we believe in Allah and in that which was revealed unto us and that which was revealed unto Abraham and Ishmael and Isaac, Jacob and Tribes and that which was given Moses and Jesus and that which was given to the prophets by their Lord; we do not discriminate against any one of them and we believe in Allah" (2:134)

What kind of Interaction the history has witnessed between the two communities. How Prophet (PBUH) interacted with Christians would give fundamental answer to this question. Let's analyze and find out:

\section{First meeting of Prophet with Christians.}

The first interaction between Prophet Muhammad and Christians took place when he was traveling to Syria with his uncle Abu Talib. Later, the Prophet had meetings and dealings with several Christians and Christian groups, including Waraqa ibn Nawfal and the Najran Christians. The agreement on the part of the Abyssinian king, Negus, to accept Muslims as immigrants in his land during the Makkan period was also a significant interaction between a Christian king and the Prophet. Prior to the start of his mission, Prophet Muhammad had encounters with some Christians on a personal basis in his daily life as a pious merchant of Makkah. However, these interactions consisted of occasional meetings and talks for the most part; they did not include any serious discussions or long-lasting communications.

\section{Meeting with the Monk Bahira}

The Prophet's first meeting with a Christian occurred when he, as a young boy aged between nine or twelve, joined his uncle's merchant caravan for a trip to Syria. The Christian whom the Prophet Muhammad (peace be upon him) encountered was the monk, Bahira, who was living in Bostra, a Roman colonial city. Monk Bahira was known for his belief that a prophet was soon to appear among the Arabs. Bahira had studied old manuscripts, where he had learned of the coming of a final prophet, and he was convinced that this prophet would appear in his own lifetime. He was particularly interested in the Arab merchants who visited Syria, to see if his conviction would come true ${ }^{16}$.

Bahira's attention was struck in particular by a caravan from Makkah which to his amazement, was shaded by a cloud that hovered closely above them. The cloud moved as the caravan moved, and did not go any further when they stopped; it was as if it were providing shade for a person or people in the group. When he also noticed that a tree lowered its branches over the caravan to provide further shade, he immediately realized that this caravan must contain an extraordinary person or persons. He invited all of the individuals in the caravan to a meal at his place, but none of their faces revealed the capacity of the expected Prophet. He inquired if there was anyone who had not joined the meal; the answer he received was that Muhammad had been left behind to watch the caravan. He was keen to see Muhammad; and when he actually saw him he realized that he carried all the 
Dialogue between Islam and West

signs that the awaited Prophet was to have, as described in his books. He told Muhammad's uncle to take him back to Makkah as soon as possible in order to guard him against possible enemies in ${ }^{17}$

\section{Waraqa Ibn Nawfal}

Prophet Muhammad (Peace be upon him) also had some encounters with one of the known Arab Christians in Makkah, Waraqa ibn Nawfal. Waraqa was a respected man of his time and a well-known Christian scholar. Waraqa was an open-minded man; he converted from paganism to Christianity and also understood the features of the revelation that had been given to Muhammad. He sincerely supported Muhammad as a Christian believer when he understood that he was the awaited prophet, after Moses and Jesus, peace be upon them. Waraqa encouraged Muhammad to continue his call, without any doubt that God would protect him. This is a fine example of cooperation between a well known Christian scholar and the would-be Prophet.

\section{The Abyssinian King (Negus)}

When the Messenger of God began to declare his message openly, the Makkan pagans started to severely oppose him and the new Muslims, making many problems for them. Several Muslims died, with even more being humiliated and alienated. The Prophet realized that Makkah was becoming a difficult place for Muslims to live in. He had his uncle as his protector; but there were many Muslims who had no protection from the aggressions of the Makkan pagans. He decided to send some of them to Abyssinia, especially those who had no effective protection; Abyssinia at the time was ruled by a Christian ruler. The Prophet told the group that King (Negus) of Abyssinia was a Christian, so they would be safe there. ${ }^{18}$ It is likely that Prophet Muhammad had some knowledge that the King was a peaceful and lenient ruler.

At the outset, eleven Muslims immigrated to Abyssinia. Later, they were joined by about 83 adult Muslims, women and men. ${ }^{19}$ Abyssinia was the Prophet's choice; he felt that Christians were closer to Muslims than the Makkan pagans. When the first Muslim guests arrived there, they met with the King. Ja'far, as leader of the immigrants, gave the Prophet's letter to the King, which read: "I have sent my cousin Ja'far to you, accompanied by a small number of Muslims; if he comes to you, receive them in hospitality..." The King welcomed them and promised to protect them from their enemies. In the royal presence a question was put to them: "What do you say concerning Jesus?" The spokesman for the group replied, "concerning Jesus we can only say what our Prophet has taught us: Jesus is the servant and messenger of God, the spirit and word of God, whom God entrusted to the Virgin Mary." When the King Negus heard this testimony, he picked up a twig from the ground and said, "I swear, the difference between what we believe about Jesus, the Son of Mary, and what you have said is not greater than the width of this twig." 20

When the people of Makkah heard that the Muslims had begun to live within the Christian community peacefully, they sent a delegation of learned people to the King to persuade him to deport the Muslims from Abyssinia. There was a debate in front of the King between the Muslims and the Makkan delegation about what and how the Muslims believed. After the end of the debate, the King rejected the requests of the Makkan's along with their gifts. ${ }^{21}$.This was the first helping hand for the young but frail Muslim community from a Christian ruler.

\section{Delegation of Najran Christians}

The most important interaction between the Christians and the Prophet was the visit of the Najran delegation to Medina. Makkah and Medina had a very small Christian population (Waraqa ibn Nawfal was one of them). The majority of Christian residents lived in Najran. The Prophet's first important encounter with Christian clergies was in the 9th year of Hijra (AD 631),

Prophet Muhammad had been sending official letters to different countries and their rulers, inviting them to Islam. Among these were two different invitations that had been sent to Najran with Khaled ibn alWalid and Ali ibn Abi Talib. At that time the Najran Christians had a highly organized religious life. Before Islam, foreign teachers had even visited the town, such as the Italian priest Gregentius, which had deepened their religious knowledge. ${ }^{22}$. Few of the Najran Christians converted to Islam; the majority of them did not change their religion after these invitations. Prophet Muhammad sent a representative to them, Mughira ibn Shu'ba, who was sent to explain the invitations and the religion of Islam. After discussions with Mughira, the Christians of Najran decided to send a group of people to visit the Prophet. The delegation was made up of about 60 well-educated Christians: A bishop, his 45 scholars, and 15 men. Their intention was to learn the nature of the revelations Prophet Muhammad (peace be upon him) was receiving. ${ }^{23}$

When the Najran delegation reached Medina, they debated with the Prophet in an investigatory dialogue for two or three days in the mosque (Masjid) of Medina. Prophet Muhammad (peace be upon him) allowed them to pray in the mosque (Masjid al-Nabawi) where the Muslims prayed. The whole incident was the first occurrence of peaceful dialogue between Christians and Muslims; it was the first time that Christians prayed in a mosque..$^{24}$ 
Prophet Muhammad warmly welcomed the Najran delegation and provided them with a place to stay in Medina, in a secure place close to his mosque. He even ordered that their tent be pitched for them by the Muslims. However, the Najran delegation and Prophet Muhammad were not able to reach a solution in theological terms. At the end of these exchanges, the Najran Christians told the Prophet: "O, Abu al-Qasim, we decided to leave you as you are and you leave us as we are. But send with us a man who can adjudicate things on our properties, because we accept you." The delegation was granted their request and a written assurance was provided by the Prophet that their lives, property, and religion would be protected. He made witnesses sign this undertaking. ${ }^{25}$.The Najran Christians were the first Christian community with whom the Prophet had a jizyah agreement. At the beginning of the meeting, they had disagreements with the Prophet about the concept of the Trinity, but later on they were able to make a social pact. This contract was an initial step that would lead to further developments. Muhammad Hamidullah states "of all the religions, the Prophet found Christianity the most sympathetic, although with certain serious reservations." ${ }^{26}$ Accepting differences to be "as they are" was the first step in establishing peaceful relations between the Christians and Prophet Muhammad some fourteen hundred years. If the present day conditions between the two communities are worst it may be out of ignorance. The interaction with Christendom has been good or we can say very much peaceful during the time Prophet Muhammad.

Initially the spread of Islamic civilisation took pace and Muslims established their rule in North Africa, Iberia, the Middle-East, Persia and Northern India. During the seventh, eighth, ninth and tenth centuries, Muslims dominated the world political stage. The relation between the Muslims and Christians virtually stabilized. In the $11^{\text {th }}$ century the Christians gained power. In Spain the Muslims collapsed in 1031 A.D. Christians dispossessed the Muslims of the island of sardine in 1061 A.D., and then expelled them from the Sicily in 1091 A.D. However, before that Mediterranean Sea was the practically a Muslim lake. The success of Christians in Mediterranean and Spain opened one more chapter of Crusades in 1095 A.D. This sort of conflict took over a religious color between East and West. The opening blow to the clash between these two communities of Muslims and Christians came certainly from crusades. Meanwhile the Ottoman Turks had appeared on the scene. They captured the Constantinople in 1453 AD and besieged Vienna in 1529 AD. According to the Bernard Lewis "from Moorish landing in the Spain to the Second Turkish siege of Vienna, Europe was under the constant threat from Islam"27.

This has not stopped here, according to the Huntington "Islam is the only civilisation which has put the survival of the west in doubt, and it has done that at least twice". This is how things started cooking between Islam and the West. The relation which prophet had maintained with Christians was almost forgotten and people looked at both these civilisations as opposites of each other. The need of the hour is to appreciate a genuine dialogue between Islam and West as anticipated by the Prophet (Peace be upon him).

\section{Bibliography}

[1] John. L. Esposito, The Islamic Threat: ,Myth or Reality, New York: Oxford University Press,1992, p.46.

[2] Samuel. P Huntington, the Clash of Civilisations and the Remaking of World Order, Simon and Schuster, 1996, p. 209.

[3] Ibid. p.46.

[4] Abul Hassan Ali Nadwi, Islam and the Modern World, Translated by Dr. Muhammad Asif Kidawi, I.I.F.S.O, 1977, p.119-122

[5] Bertrand Russell, A history of Western Philosophy, London, George Allin and Unwin, 1946, p.304

[6] A.E McGrath, Reformation Thought (An Introduction). Oxford, Basil Black Well, Ltd. 1988, p.303.

[7] Abul Hassan Ali Nadwi, p. 115-117.

[8] Youssef Al-Qardawi, Islam, the Civilisation of the Futurehttp://www.thomasmichel.us/modern-civilization.html

[9] Muhammad Asad, Islam at the Crossroads, Lahore, 1955, p 55-56.

[10] Samuel. P Huntington, p. 45.

[11] Abul A'ala Maududi, Islami tehzeeb aur uske usool-o-Mubadi, p.9.

[12] Syed Ameer Ali, The Spirit of Islam, Islamic Book Trust, Delhi, 1993, p.30-51 Samuel. P Huntington, p. 209.

[13] Martin Lings, Muhammad: His Life Based on the Earliest Sources, Allen \& Unwin, U.K., 1983, p. 29.

[14] For details P.S: Ibn Hisham, Abd al-Malik, al-Sirat al Nabaviyyah, Egypt 1955, p. 180-183.

[15] Al-Bukhari, Muhammad ibn Isma'il, Sahih al-Bukhari, Dar al-Fikr, (Arabic-English Edition) p. I, 2-3

[16] Ibn Hisham, I, p. 217-221.

[17] Ibid. 221-230.

[18] R. Marston Speight, God Is One: The Way of Islam, New York: Friendship Press, 1989, p. 1-2.

[19] Ibn Hisham, I, 233-238.

[20] Muhammad Hamidullah, Muhammad Rasulullah: a concise survey of the life and work of the founder of Islam, Stockists, Habib, 1974, p. 103.

Ibn Hisham, I, 575.

Ibid. 575-577.

Muhammad Hamidullah, Muhammad Rasulullah, p. 76.

Prof. Masudul Hasan, History of Islam, Adam Publishers, 2007, I, Ed, p.454-455. 